\title{
Structural Models of Titles and Subtitles (on the Materials of the English and Azerbaijani Languages)
}

\author{
Ilaha Zeynalli ${ }^{1}$ \\ ${ }^{1}$ Azerbaijan University of Language, Azerbaijan \\ Correspondence: Ilaha Zeynalli, Azerbaijan University of Languages. E-mail: izeynalli@yahoo.com
}

Received: October 1, 2015 Accepted: November 10, 2015 Online Published: November 30, 2015

doi:10.5539/ijel.v5n6p145 URL: http://dx.doi.org/10.5539/ijel.v5n6p145

\begin{abstract}
This paper explores the investigation of structural models of titles and subtitles on the materials of the English and Azerbaijani languages. The problem has been studied diachronically at first on the materials of the English language and then these issues have been considered on the materials of the Azerbaijani language. Attempts have been made to explain structural models of titles in the following paragraphs of the article.

In this paper a special attention is paid to the expressive devices and semantic variations. Alongside the semantic peculiarities, structural problems associated with the titles and subtitles have been explored as well.

Titles and subtitles of the texts as it is mentioned above is studied in diachronic-historical aspect, mainly dealing with the titles and subtitles of the works of art-literature. As to the view of the author this paper is of practical and theoretical importance and which has been substantiated with theoretical-scientific provisions. In the investigation of the problem comparative-typological, diachronic method has been used.
\end{abstract}

Keywords: text, unit of a text, title, subtitle, context

\section{Introduction}

While studying the structural models of titles and subtitles it becomes clear that they depend on a number of factors. One of these factors can be determined as the diachronic-historical principle. The names of the literary pieces and their titles have been subjected to a certain changes. Investigation of these problems on the materials of the English and Azerbaijani languages requires systematic view at literary pieces in both languages. In the paper the problem first has been described in English and then in the Azerbaijani language, in the chronological order. In the following stage the structural models of titles are studied in the comparative aspect.

\section{Diachronic Approach to the Study of Titles and Subtitles}

The forms of titles used by the British author in the literary pieces in the XVII-XX centuries have changed as the time went on. From this view-point specific features are observed in the use of these titles.

At the initial period of foundation of literary pieces titles were used. In the history of both, the English and Azerbaijani languages, being transferred from generation to generation these titles orally have survived until now. After the adoption of Christianity in England monarchs-scientists started writing different myths, legends. For example, epic poem "Beowulf" written by the handwriting of the X century, has reached safe-and sound until the present century.

After England was occupied by the Norman's in XI-XIII centuries three-languaged literature of the feudal world begin to be developed. Church literature was written in Latin, poems and poetries on knights were written in French, but English legends, were written in the Anglo-Saxon languages. In this period religious-didactic anthology called "The Cambridge Tales" was written as a collection of love and satiric poems. Among the other works of the time were "The Play of Adam" (St. Anselm of Canterbury, 1093), "The History of the Kings of Britain" (Geoffrey of Monmouth, 1136), "Layamon's Brut" (Layman, 1205). These works, being chronicles were written in Latin. The novel on Knighthood called "Havelock" belongs to 1250-1300 years. It is clearly seen from the names of above-mentioned works that the authors wrote more about ancient legends and myths. The titles of the works reflecting the chronicles of historical events were given by the name of the historical personalities. Among the English literary monuments of the XIV-XVI centuries three were the works, named "The Canterbury Tales", Mort d. Arthur (Sir Thomas Malory), "Utopia" (Sir Tomes More). At the end of the 
XVI and at the beginning of the XVII centuries, the names of Shakespeare's works from the view of titles cause our interest. He named the chronicles on the English history by the names of monarch heroes: "King Henry VI", "King Richard III". The tragedies of Shakespeare were called by the names of heroes, such as: "Hamlet", "Othello", Romeo and Juliet" etc. Besides a number of comedies having distinctive titles were also created: "The Taming of the Shrew", "O Midsummer Night Dream", "Much Ado About Nothing" etc.

Literary prosaic work of XVII-XVIII centuries in the English language, as to their language peculiarities were close to the language of the documents. These works sometimes remind of chronicle, because very often they were written in the form diaries. In the titles of the literary works of this period emotionality is missing. Titles very often were given in the form of brief summary on the plot. There exists information on the hero of the work and on the events taking places at the time. The long titles such as, "The life and strange Surprising adventures of Robinson Crusoe, of York, Mariner" (D. Defoe), "A Journal Made in Summer of 1994 through Holland and the Western Frontier of Germany" (A. Radcleffe) etc. remind us of business like character. I. R. Galpern shows that in this period for the titles of works of prose not breaking the truthfulness of narration was characteristics (Galpern, 2009).

The titles of British authors of the XIX-XX centuries strictly differed from the titles of the works of the previous years. This, before everything, was associated with the change of the contents of literary works. Writers were already not interested in the description of adventures. This period attracts our attention by the increase of the level of both, the writers and the readers. Gradually the works of deeper senses were written. Human beings and their fates began to turn to the main themes for the writers.

Personal names in the works of British authors as titles were often used. Such titles were more widely- spread in the XIX century. In such works the names of the main hero were in the focus of attention of both, the readers and writers "Oliver Twist", "David Copperfield" (Ch. Dickens), "Emma" (J. Austen), "Jane Eyre"(Ch. Bronte), "Romulo" (G. Eliot) etc. Titles-anthroponomy as the mentioned one member sentences, as to the semantics of the subject can be belonged to sentences with persons. By expressing the personal name in the title, the author stresses the only "representative" of the text in the first plan.

The number of the literary works named by common names were increased in the XX century. For ex. "The Alteration" (K. Amis), "The Enigma" (Y. Foweles), "The Summing-up"(W.S. Maugham) etc. In such works the authors try to express the main idea both by one word-laconically and in the figurative way. Common nouns or the titles expressed by names are hints to the central character, in all the works they follow the main theme.

\section{Types of Titles}

The fact that the names are established in the form of word combinations were widely-spread. Word combinations are formed by subbordinative and coordinative relations. Coordinative relation exists among the words of the same rights in relation to one another, but grammatically having links with one another, and not depending one another, one not explaining the other in any way. In the titles of literary works it is possible to observe this feature.

The number of the word combinations formed by means of coordinative relation among the titles of literary works in the English language of the literary works of the XVIII-XX centuries, are not few. "The Moon and Sixpence" (W. S. Maugham), "Nuns" and Soldiers (I. Murdoch), "Decline and Fall" (E. Waudh) etc. The joining conjunction "and" serves to reflect the main conflict of the work, to oppose the heroes and main themes.

In the literary works of the XVII-XX centuries in the English language the use of titles with subbordinative tie in word combinations were widely-spread. "The Return of the Native" (T. Hardy), "The Devoted Friend" (O. Wilde), "The Time of the Angels" (I. Murdock) etc.

In the subordinate word combinations the use of the objective case bears a number of important features. In such constructions when the first component is a noun expressing lifeless notion, the transition of the meaning to the circle of living beings shows itself.

For example, "The Razors Edge” (W. S. Maugham), "The French Lieutenants Woman” (J. Fowels).

One of the types of titles is a sentence. In such a title not only the subject and predicate, but secondary sentence members are used as well. For ex: "Salt is living"(J. B. Priestly), "Time must have a stop" (A. Huxley). Such sentences are characteristic for daily speech. By using the sentences of daily use in the titles of literary works expressiveness and load of meaning strengthen.

Thus, in comparison with a text, despite it being short or in its isolated position, title in the literary works play an important role, expresses the concept of the text. Title carries out the function of dictum. Title, being a part of the 
text establishes semantic relations with the whole text. Title concentrates the main idea of the text in itself. It reflects semantic multidimensionality. Cognition of the text is a gradual process. Its meaning becomes clear as the reader reads on the text.

While considering the titles of the text in historical aspect the title specimens of works in the English language show us how these titles change and develop in the historical process. Generally speaking, here we can obviously discover the tendency of development of titles from many words to fewer ones. In the titles of still more ancient times we can see that exploitations and commentaries take place. We can consider this problem in the Azerbaijani titles as well.

\section{Consideration of Azerbaijani Titles of Literary Pieces}

Undoubtedly, in the Azerbaijani literary pieces, as it is in English works the initial specimens of written monuments were just the specimens of the folk literature. Azerbaijani bayaties (Note 1), lullabies, riddles, existed without titles. But in the folk created tales and sagas, titles found places for themselves. Tales and sagas as to the volumes are big ones. In legends, myths and text of mythological types, titles have been noted as well. After the literature of author's creation started, increase of types of titles is observed as well. To learn the development features and structural models in the Azerbaijani literature more closely, it is necessary to apply both to the folklore and to the ancient written sources. The name of the most ancient written monument is: "Kitabi Dedem Gorqut ala lisani Taifeyi Oguzan". The saga "Kitabi-Dede Gorgut" (the book of father Gorgud) has been divided into chapters. Besides, in other works, a brief introduction is given. In introductions names and tittles are missing. The work consists of 12 chapters. The names of these chapters are like these: "Dirsa xan oğlu Buğac xan boyunu bəyan edər, xanım hey!...”, Yazan bəy oğlu Uruz bəyin tutsağ oğlu Bamsı Beyrək boyunu bəyan edərl. xanım hey..." (Qazan bəy oğlı Uruz bəgin tutsaq oldığı boyı bəyan edər, Xanım hey!...”, "Duxa Qoca oğlı Doli Domrul boyın bəyan edər, xanım hey!...", "Qanlı Qoca oğlı Dali Domrul boyını bəyan edər, xanım hey!", "Qazllıq qoca oğll Yegnag boyını bəyan edər, xanım hey!...”, "Basat Dəpəgözü oldürdigi boyı bəyan edər, xanım hey!", "Bəkir oğlı Omranın boyın Bayan edər", "Uşan oğlı Səgrək boyını bəyan edər", "Salur Qazan tutsaq olub oğlı Uruz çıqardığı boyu bəyan edər", "İ̧̧ oğuza Taş Ŏguz asi olub Beyrag oldüği boyı bayan edar".

We see that as it is with the ancient literary specimens of the English literature, here too the name of each chapter bears the characterization of the general description of very event. In some chapters the titles are longer, but in some others, they are relatively short. Each of these titles gives information on the contents of either this or that chapter, or on the saga as a whole. In the ancient written monuments not only other component not included into the complex of titles was used. The fact that the name of the work gave brief information on the contents of the literary piece is characteristic for the saga "Koroglu" (Son of the blind man) as well. Here too, information on the each chapter is devoted to, find its reflection.

For example, "Koroglunun Arzuruma səfəri”, "Koroğlunun Bağdada səfəri” etc.

In the classic Azerbaijani language the choice of titles as to the heroes, are especially observed. Let's consider the names, entering "Khamsa" of Nizami Ganjavi: "Leyli va Macnun", "Xosrov va Şirin", "Ísgandarnama", "Sirlar xazinasi", "Yeddi gözal". In three of the titles the names of the heroes are used.

The title in the work "İskəndərnamə" has been devoted to only one hero.

The work which came under the pen of Ali belonging to the Azerbaijani written monument of the XIII century is called "Qisseyi-Yusif". In the internal titles of the work the contents of the chapter is expressed in a general form. For ex.:, "Fasl fi hasbi-ahvali Yusif" etc. The similar features can also be observed in the works of Yusif Maddah, named "Varqa va Gülşah" and also in "Dastani -əhmad Hərami" and in some of the other works belonging to the XIV century.

Internal titles in Fizuli's work "Leyli va Məcnun" have been formulated with the same principles. For ex: "Bu, şüküfeyi-gülzari-tövhiddir va növbaveyi-Bustani-təmciddir", "Bu minacat dəryasindan bir cövhərdir va tazarra madənindən bir gövhərdir”, "Bu sağiyi-bəzmə badə üçün xitabdır”, "Bu tuğrayl-misali-məhəbbətdir və dibaçeyi-divani-möhnatdir etc.

\section{Titles in the English Literature of XVII-XIX Centuries}

Titles in the English literature of XVII-XIX centuries also distinguished by their descriptivism. In the initial period of development of English literature the titles of a piece of literature were wide and explainable. For ex: "Travel into Romte Nations of the World, in Four parts. By Lemuel Gulliver, First a Surgeon, and then a Captain of several Ships" - J.Swift, "The Life and Opinions of Tristram Shendy, Centleman", "A Sentimental Journey through France and Italy by Mr. Yourick" - L. Sterne. V. A. Kukharenko in his investigation on XVII 
century indicated the title of the only work of the American writer Meri Roulandson. This name-title was about a brief annotation: "The sovereignty and goodness of God, together with the faithfulness of his promises displayed; being a narrative of the captivity and restoration of Mrs. Mary Rowland-son, commended by her, to all that desires to know the lord's doings to, and dealings with her. Especially to her children and relations. The second Addition corrected and amended. Written by her own, hand for her private use, and now made public at the earnest desire of some friends, and for the benefit of the afflicted"(5, s. 94). The title-name of Daniel Defoe's work, known as "Robinson Crusoe" is also an annotation type: "The Life and Strange Surprising Adventures of Robinson Crusoe of York, Mariner: Who Lived Eight and Twenty Years, All Alone in an Uninhabited Island on the Coast of America, Near the Mouth of the Great River of Oroonoque; Having Been Cast on Shore by Shipwreck, Wherein all the Men Perished but Himself. With An Account How He Was at Last as Strangely Delivered by Pirates. Written by Himself".

The name of Daniel Defoe's work "Moll Flanders" also contains a summary: "Fortunes and Misfortunes of the famous Moll Flanders, Etc. Who Was Born In Newgateand During a Life of Continu'd Variety For Threescore Years, Besides Her Childhood, Was Twelve Year a Whore, Five Times a Wife (Whereof Once To Her Own Brother), Twelve Year a Thief, Eight Year a Transported Felon In Virginia, At Last Grew Rich, Lived Honest, and Died a Penitend. Written from her own Memorandums". The work which came under the pen of C.Dickens in 1849 was named like this: "David Copperfield or the Personal History, Adventures, Experience and Observation of David Copperfield the Younger of Blunder stone Rookery (which he never meant to publish on any account)".

It is worth mentioning that when the very piece of work was published in the following year its name became simply "David Copperfield" derived from shortening of the name of literary pieces.

Historic evaluation of titles shows that, in the initial periods the authors thought it purposeful to give some information with the titles (Lamrina, 2000). Beginning with the XIX century, descriptive titles began gradually to disappear. S. D. Krijijanovski wrote about this tradition: "It in XVII century D.Defo named his book in 50-60 words, at present time Andrey Beliy managed doing it with one letter "A" (Krejejanovski, 2006). In XX century we can meet any structural type of titles. This is on one hand associated with the inclination of protecting a certain tradition, on the other hand it is associated with the complication of the semantics of the titles. Titles-symbols, titles-allusions, titles-metaphors, titles-cites are in fashion now. The author with such titles as if invites their readers to the joint creative process. In spite of the fact that numerous investigations have been devoted to idio style, from the view of creation of literary texts, the parameters of this style, we can say, that have not been properly studied associated with titles (Kolshanskiy, 1975). The fact that titles were created with the view of different factors-unification of detective and gothic elements, inclusion of symbols, metophorization and other factors of such kind have been rooted for the creation of different associations of the created information. The author in such titles as if cheats the reader, prepares the reader to be rooted to see the development of distinctive plots in different directions. The noted feature increases interest of reader to the piece of literature. The reader himself tries to open the puzzle put forth in the work. Sometimes the title creates the imagination of a plot, seemingly to be interesting for him while reading the piece of literature.

Naturally all the points of a literary text as a linguistic object increase the role of the author as a language and creative personality. The author turns the language means to aesthetic transformation and changes it. The approach of the author to the text, his views on the text, the author's attitude to the reality penetrate into the text, present the role and function of each of them (Odintsov, 1980). Each of literary works is the product of an individual labour. Here we may came to the conclusion that, the investigation of literary texts belonging individually to the author, at present- day linguistics can't in any way pass beyond idiostyle. Idiostyle, by idiolect means, by language units represents itself to different means and involves the individual attitudes of text creator (Ledeneva, 2001). In the investigations devoted to this issue the deflective point is that titles were not taken into consideration. Title is one of the important indicators of author's individuality.

O. Y. Bogdanova considered the issues of characterization of the literary works as to the janres and distinguished the following groups: 1) Noun+ of (preposition) +proper name ("The Pecture of Dorian Gray" O. Wilde, "The Ordeal of Gilbert Pinford" E. Waugh): 2) Noun+ of + noun (The return of the Native) T. Hardy, "A Woman of No Imporance" O. Wilde, "The Time of the Angels" L. Murdoch, 3) adjective+noun ("The Happy Prince" "The Devoted Friend") (Bogdanova, 2009).

O. Y. Bogdanova's classification is associated with grouping of roman names. From the same position while copying the problem on to the names of stories he introduces other structural models. It is worth mentioning that the classification of the author includes the word combinations consisting of only two words. But the titles of 
novel are restricted only with the names of this type. Naturally, in the titles of individually taken janres a certain general feature is observed.

In the English literature the fact that names of short stories are given in the form of a widened sentence is in fashion. Subject establishing the name, predicate and secondary members of the sentence were used. For ex: "Diddling Considered as one of the Exact sciences" (Poe, 1843), "The show is Confiscated" (Word, 1860), "It is You, My Sister, Who Must be Protected" (Moraga, 1998). Later on this story janre while developing relatively tended to short names, nevertheless long names did not completely disappear. For ex: "When I Woke Up This Marning, Everything, I Had Was Yone" (Boyle, 2003) Here we must mention one more problem. The Titles of the works of the later period already did not explain the contents, but idea, concept. Modern authors choose shorter names for their works.

"Bears Discover Fire" (Bisson, 1995), "I am not Your Mother" (Mattiison, 1995). It is necessary here to point out passive constructions which were not used before For ex, "Marriages Are Made in Haven" (Gladden, 1940)

In the Azerbaijani literature in the latest years different forms of titles were formed. Analysis shows that the titles of literary works in the Azerbaijani language have developed from the titles containing many words, to titles with fewer words. It becomes clear from the analysis on the basis of materials in the English and Azerbaijani languages, titles differ as to the structure as well. Titles possess the following structural types: 1) one word titles; 2) coordinative word combinations; 3) subbordinative words combinations; 4) sentence.

One-word titles in the English language belong to different parts of speech, mainly to nouns. For ex: "Cat" (Munro, 1904), "Accomplice" (Bynum, 2004), "Hands" (Anderson, 1919), "Gifts" (Boyd, 1995), "Fur" (Munro, 1916), "Tea" (Munro, 1916), "Vinegar" (Todd, 2004), "Bread" (Alameddine, 2002), "Crytology" (Michaels, 2004), "Dusk" (Munro, 1904), "Immorality" (Li, 2002), "Presence" (Miller, 2001). Common nouns being countable nouns are used both in singular and plural forms. For ex: "Cat" (Munro, 1904), "Immorality" (Li, 2002), "Presence" (Miller, 2001). The usage of nouns in the plural form in titles are observed as well. For ex: "Hands" (Anderson, 1919), "Gifts" (Boyd, 1995). In the English language uncountable object and nouns expressing abstract notions are used in the titles. For ex: "Tea" (Munro, 1916), "Vinegar" (Todd, 2004), "Bread" (Alameddine, 2002), "Crytology" (Michaels, 2004), "Dusk" (Munro, 1904), "Dusk" (Munro, 1904), "Immorality" "Presence" (Miller, 2001). Some scientists think it unimportant to divide nouns into two parts, concrete and abstract nouns (Cherneyko, 1997). In this research work making such a division is relevant, because imagination of non-substantial referent influences on the essence of the problem. Usage of such a name in the title may arouse different associations in the readers. For ex: The word "Dragon" creates a certain associative characters in the reader. The mentioned point increases the possibility of fancy in the reader associated with the minimal degree of substantiality or generally non-substantiality of the object. In the English language, the fact that the countable abstract nations are used in plural often shows itself. For ex: "Exchanges" (Morris, 2005). Analysis shows that, in the XXI century, in the short English stories such names are more used. At this time the level of informativity of the title is lower and as informativity lessens, the fancy possibilities of the reader increases. The titles verbalized by common nouns and the titles denoting persons are divided into different types. In the literature in the English such titles have the following types: simple type "Mother" (Anderson, 1870), title type used with the definite, "The applicant"(Bierce, 1870) the title widened with compound nouns article, "The story Teller" (Munro, 1904), the title used with personal pronouns, but there are a few of them, "She" (Atwood, 1983) "Him"( Munro, 1904) - personal pronoun in the objective case.

\section{Conclusion}

For titles, specification and generalization are characteristic. Specification is associated with a certain event or essence in the text. Generalization takes place by the widening and specification of the meaning all through the text. Title belonging to a concrete event or a concrete hero, during the revelation of the text bears more general character, such a feature more often shows itself in the titles expressed by personal names. Policemy, dynamism, link with the text, correlation, specification and generalization are the main features of the titles. Titles have possessed direct or indirect belonging to the titles. Sometimes, this belonging remains beyond the text and finds its explanation by extra linguistic factors. Titles while being repeated in the text, may remain in the implicit form all through the plot. Experiments show that specification and generalization are common features for the titles. Specification is associated with a certain event or essence in the text. Generalization takes place by the widening or specification of the meaning all through the text. A title belonging to a concrete hero or to a concrete event bears a generalized character as the revelation of the meaning of the text goes on. Such a feature shows itself more conspicuously in the titles expressed by proper names. Policemy, dynamism, association with the text, correlation, specification and generalization are the main features of the titles. Titles have possessed a direct or 
indirect belonging to the text. Sometimes this belonging remains beyond the text, and finds its explanation by extra linguistic factors. Titles as being able to be repeated, may as well remain in the implicit form throughout the plot.

\section{References}

Bogdanov, O. (2009). Title as the semantic-element composition of a literary text (On a material of the English language). Abstract Dis. ... PhD.

Cherneyko, L. O. (1997). Lingvofilosofskoy analysis abstract name. M.: MGU.

Halperin, I. R. (1981). Text as an object of linguistic research. M.: Nauka.

Kolshansky, G. V. (1975). The ratio of the subjective factors of communicative language. M.: Nauka.

Krzyzanowski, S. D. (2006). Poetics titles. SPb., M.Vyssh. School.

Kuharenko, V. A. (1987). Workshop on the interpretation of the text. M.: Education.

Lamzina, A. V. (2000). Introduction to Literature. Literary work. Basic concepts and terminology. M.Vyssh. School.

Ledeneva, V. V. (2001). Idiostyle (to clarify the concept). Philology.

Odintsov, V. B. (1980). The style of the text. M.: Nauka.

\section{Note}

Note 1. Bayati: specific literary janre.

\section{Copyrights}

Copyright for this article is retained by the author(s), with first publication rights granted to the journal.

This is an open-access article distributed under the terms and conditions of the Creative Commons Attribution license (http://creativecommons.org/licenses/by/3.0/). 